\title{
Wildlife Forensic: Current Techniques and their Limitations
}

\author{
Nishant K, Vrijesh KY* and Ajay KR \\ State Forensic Science Laboratory (SFSL), Ranchi, Jharkhand, India
}

"Corresponding author: Vrijesh KY, (Forensic Expert: Biology/DNA/Serology) SFSL, Ranchi, Jharkhand, India, Fax: +91-0651-2270095, Tel: +91-0651-2270016 (O), 8853228497, E-mail: yadav.vrijesh@gmail.com

Citation: Nishant K, Vrijesh KY, Ajay KR (2017) Wildlife Forensic: Current Techniques and their Limitations. J Forensic Sci Criminol 5(4): 402

Received Date: June 18, 2017 Accepted Date: August 28, 2017 Published Date: August 29, 2017

\begin{abstract}
The wildlife includes undomesticated and diverse forms of floral and faunal species, which is essential for ecological balance and human survival. The poaching and illegal trade has resulted in sharp decline of many wild species of flora and fauna around the world. The need of the time therefore is to utterly focus on wildlife protection for the sustainable development of biosphere and future viability of human beings. In this review we have focused on different techniques being utilized in wildlife forensic science for identification of wildlife species as well as their geographical origin. These techniques can be employed to control the wildlife crimes and convict the criminals involved in illegal trade of wildlife flora, fauna and their products. These techniques include footprints analyses, morphological and anatomical studies, and microscopic examinations of the body parts as well as molecular biology techniques such as serological, mitochondrial DNA, rRNA, and protein analysis. The well documented methodologies and techniques with their cons and pros in this review has been thoroughly discussed and will certainly benefit the court of law and the scientists working in this area to bring down the wildlife crime rates by scientific investigations.
\end{abstract}

Keywords: Species identification; Illegal trade; Wildlife crime; Mitochondrial markers; Geographical origin; Molecular techniques

\section{Introduction}

Wildlife crime includes an illegal trade, possession of wildlife animal, plants and their products which comes under the action against national and international law $[1,2]$. Currently trade of Illegal wildlife flora and fauna takes place all over the country [WWF-IND, 2014]. Tibetan Antelope (Pantholops hodgsonii) has moved from Endangered to Near Threatened (IUCN 2016). The main cause is commercial poaching for the shahtoosh which is used to make shawls. Bornean Yellow Muntjac (Muntiacus atherodes) are Near Threatened. The major threats are hunting for meat, skins, and traditional remedies (IUCN 2016). Grey Parrot (Psittacus erithacus) was uplisted from Vulnerable (VU) to Endangered (EN) in 2016. International trade is a significant threat to the global population, and is estimated to have caused a decline of at least 50\% over the last 47 years (IUCN 2016).

India has a strong legal and policy framework to regulate and restrict wildlife trade. However, strong policies and implementation is highly required in the present Indian scenario. Under the wildlife protection Act (WPA) 1972, trade of wild animals, plants and their derivatives is prohibited. Wildlife products are third in the row of illegal trade after narcotics and firearms $[3,4]$. The wildlife crime is increasing rapidly and area covered under this is unknown. The major cause of exploitation of wildlife natural resources is illegal trade for medicinal needs (anti-aging and growth medicines), elephant ivory, wildlife animal skin, sport, food and clothing [5]. In the world, more than 60 to $70 \%$ population depends on herbal medicine concern to health requirements [6].

The illegal trade in wildlife mammals, birds, insects and reptiles is very well networked across the world and every year thousands of wild animals, birds, insects and fish are sold across the world (WWF IND 2014). In India to protect wild animals project have been launched for many species including Sea turtle, Crocodile, Hangul (Red Deer), Tiger, Elephant and one horned rhino. One horned rhinos are poached for their horns. Recently, Indian (One Horn) Rhino Vision 2020 was established by ministry of environment and forests (2016). The vision of this program is to increase number by the year 2020. The illegal trade of seahorses and pipefish is occurs from Tamil Nadu, Kerala, Maharashtra and Karnataka in India [7]. The major reason of exploitation is use of it in antiaging medicines, asthma, high cholesterol, goiter, kidney disorders and skin afflictions and infertility [5]. In the world, diagnostic markers for species identification in wildlife forensic are footprints analysis at the crime sites, morphological study of the species, microscopic examinations of the body parts, anatomical studies and serological methods. This is based on characteristics of hair, long bones, species-specific tooth morphology and other associated traits [8]. The evidences from which identification of species in wildlife forensic being done are cooked and dried meats, dried shark fins, egg shells, animal hairs, bone, ivory, rhinoceros horns, turtle shell, feathers and fish scales [9-18]. 
Recently, DNA markers are being used for accurate identification of species. Identification of species based on DNA microsatellites was developed in 1999 thereafter being utilized in identification of species from several samples [19]. Identification of species based on Mitochondrial DNA (mt-DNA) is also being utilized. National Center for Biotechnology Information (NCBI) is the repository data base of DNA sequences from different species which helps in similarity search after PCR amplification and sequences produced with genetic analyzer from wildlife evidences. The repository of DNA sequences and markers are not available for a majority of wildlife flora and fauna in present scenario of wildlife forensic. There is needed to make co-ordination globally to develop repository DNA sequences of different wildlife flora or fauna and DNA markers to strengthen wildlife forensics in India. Thus, illegal trade of wildlife flora-fauna and their products would be diminished with the help wildlife forensics.

\section{Wildlife crimes}

Wildlife crime is a global issue in present scenario because of illegal trade of wildlife flora, fauna and their products that takes place all over the country. Also it includes possession of and/or their derivatives without valid authorization. Sometimes there is trade (within a country or outside as export) of the scheduled species or their derivatives. Rare but is not uncommon is the wildfire that occurs as a natural calamity for the wild. Humans sometimes invade the wild with injurious substances, such as burning cigarette stub, in a National Park, Sanctuary, Community Reserve or a Tiger Reserve. Most of the criminals or poachers as per their mens rea are involved in wild life crime for food, fuels, fodder, handicrafts, building materials, clothing, ornaments, or of private or scientific purposes.

\section{Crime scene investigation, collection and preservation of samples}

The main purpose of inspection of wildlife crime scene is the identification of the species \& the cause of death; i.e. linking the suspected wildlife criminals, victim and the crime spot. The basic care taken under consideration is to demarcate the area to be searched, prohibit overcrowding, wear sterile gloves before collecting the samples, creating a crime map (crime map is a visual summary of a crime), preservation, packaging and forwarding. This section mainly includes what precautions should be taken initially in samples collection prior to reach in forensic laboratory (Table 1).

\begin{tabular}{|c|c|c|}
\hline Specimen/Samples & Preservation & Packing \\
\hline Tissues & $10 \%$ formalin & $\begin{array}{c}\text { Wide mouthed, leak-proof glass } \\
\text { or plastic }\end{array}$ \\
\hline $\begin{array}{c}\text { Visceral Organs(liver, kidney } \\
\text { etc), blood or suspected } \\
\text { contaminated food }\end{array}$ & $\begin{array}{c}\text { Proper cold storage } \\
\text { (Refrigeration or freezing)and } \\
\text { storage in super saturated saline } \\
\text { solutions }\end{array}$ & $\begin{array}{c}\text { Clean glass, plastic or suitable } \\
\text { wrapper that does not harm the } \\
\text { collected samples }\end{array}$ \\
\hline $\begin{array}{c}\text { Biological fluids (like blood, } \\
\text { saliva) or bones, teeth, freshly } \\
\text { preserved soft tissues }\end{array}$ & $\begin{array}{c}\text { The stained /wet samples (items) } \\
\text { should be properly dried before } \\
\text { packaging }\end{array}$ & Paper packets \\
\hline
\end{tabular}

Table 1: Samples detection, preservation, packaging and forwarding

\section{Examples of evidence items to be sent for examination}

Blood samples (in a fresh or dried condition), Tissue samples (fresh/dried in frozen condition), Bone, Teeth, Claws, Tusks, Hairs, Hides, Furs, Feathers, Leather goods, Poisons, Pesticides, Stomach contents, Projectiles (bullets, arrows), Weapons (rifles, bows, traps), Woods, Leaves and anything else concern with crime.

\section{Labeling}

Samples should be properly marked with numerals or alphabets and their description should be provided in the forwarding notes with a crime scene drawing containing the information about the places from where these samples have been collected.

\section{Chain of custody}

Samples should be packed properly and sealed. A sample of the seal should also be provided in the forwarding note. Maintaining chain of custody is an important part of crime investigation to ensure no tampering has been done during movement of parcels.

\section{Wildlife Crime Analysis and Forensic Techniques}

It includes the application of forensic science (application of science to the matters of Law) in solving legal matters related to Wildlife Crimes. The identification of seized materials and the protected species are required to send to the forensic laboratories dealing with wildlife crimes or wildlife related research institutions. Some specific characteristics of species or seized materials are employed for wildlife species identification in forensic laboratories. Currently the techniques being utilized for wildlife species identification are footprints analysis at the crime sites, morphological study of the species (includes microscopic examinations of the body parts, anatomical and histological studies), serological methodology and molecular biology techniques. For the determination of geographical origin of the organism most commonly employed techniques are inductively coupled plasma atomic emission spectroscopy (ICP) and radiotracer techniques in modern analysis of wildlife related evidences. 


\section{Morphological Analysis}

The morphological or physical characteristics are the simplest way of wildlife forensic method in the identification process of evidences and least expensive forensic analysis. In the identification of species based on morphological characteristics of wildlife flora and fauna provides important clues based on external appearance. Different species generally possess distinct physical appearance like skin coat color, pattern of coloration, eyes, pinna, tails, ivory etc. Ivory, illegally traded from Asian or African elephant is a form of dentine, has a unique characteristic pattern known as schreger. It also has another characteristic of angled pattern that forms the basis of identification even between the species [20,21]. When whole skin or skeleton are present as an evidence, then morphological, anatomical and microscopic analysis are helpful in identification of the species [22]. Expertise and database of known or reference sample becomes very crucial in identification based on morphology. For example when skin evidence of animals is seized hair analysis and comparison with reference sample are essential in identifying the species of origin. Since morphological test is the test of form and structure of an evidence (hairs, feathers, skeletal remains, whole or small parts of animals, birds, leaves, flowers, wood, skins of reptiles amphibians, fish, scales, insect and other wildlife animal, plants and their products). Such an evidence sample is analyzed, matched with reference samples like taxonomic keys and monographs of the species available. The major problems with morphological identifications is the non-availability of the whole animal or its intact parts preserved as such and the morphological analysis is again limited to the level of genus or its higher taxonomic level.

\section{Footprints Analysis}

Footprints of wildlife species are important evidence in the forensic analysis of species. Footprints are impressions of animals foot on surfaces where they walkout or places of their captivity. The type and age of the species identification is based on the pattern of the footprints and their size. The major problem with footprint impressions based identification of species includes is undetectable footprint on hard surfaces and sometimes these footprint sites are often contaminated by presence of other animals.

\section{Microscopic examination}

It includes the morphology, elemental analysis and cuticular scale pattern of the hair [23]. Hair plays a vital role which can be used to identify the species [24,25]. Scanning Electron Microscope (SEM) can be utilized for the identification of the animals based on hair evidences [26]. Scanning electron microscopy provides higher range of magnification and coupled Energy Dispersive Spectra (EDS) which will leads to the identification of geographical region by elemental analysis like Sodium, Potassium, Calcium and Sulfur [23,27]. Hair scale pattern of different species have been reported in Australia and Europe for the mammalian species $[28,29]$. The major limitations of microscopic techniques are that it requires samples for microscopic examination in well preserved.

\section{Serological techniques}

Serological techniques based on interaction between antibody and their cognate antigen just like lock and key model. Species specific antibodies are used for the identification of species of origin of the biological evidences. The concerning problems with serological techniques is the non-availability of species-specific antibodies in our laboratory. Also there is wide report that crossreactions of antibody in non-target species sometimes produce positive results. Therefore, it is only considered as a presumptive test in the forensic analysis [30-33].

\section{Molecular biology techniques}

DNA molecular techniques have been used in wildlife forensic investigation concern with the poaching of animals (mammals, birds etc) from national parks and protected areas in South Korea, Italy and other countries [34]. Molecular techniques are proven to be more reliable comparison to others techniques such as anatomy, morphology, serology as well as microscopic. Initially, DNA-based methods utilized were Random Amplified Polymorphic DNA (RAPD), Amplified Fragment Length Polymorphism (AFLP) and Random Fragment Length Polymorphism (RFLP) [35-37]. Limitations of these methods are reproducibility and the generation of a reference database. The quality of template, buffer, dNTPs, and primer concentration affects the band patterns [38]. It requires several restriction enzymes therefore, becomes difficult to separate the samples with same restriction patterns [39]. Much of work has been done on human DNA for identification of human and being utilized to solve the different cases like sexual assault, murder cases, burnt cases and accidental cases etc nationally and internationally. In the field of wildlife forensic DNA marker based work is on progress and needed to explore more and more for wildlife flora and fauna.

To prevent the elephant poaching for Ivory work on DNA extraction and amplification for nuclear and mitochondrial DNA have been done to detect the origin [40]. The DNA markers have been used in species identification and relationship establishment between different species. It also has been reported that for conservation of genetic biodiversity forensic was merged with the biological research in Canada and established the Natural resources DNA profiling \& Forensic Centre (NRDFC) for the extraction and DNA profiling of wildlife animals. However, in the country like India such an organization has to be organized for profiling and data base preparation of wildlife animals. It also have been reported that molecular population genetics was utilized to trace the suspect in case of wolf killing in Italy [41].

The biopolymer like protein which is comparatively more stable than DNA polymer is new emerging field for identification of 
populations. [42-45]. There is also need to optimize protein based marker for identification of different populations rather than only DNA based identifications. Therefore, much needed to focus on screening of an unique protein marker which provide unique discrimination like provided by DNA based markers.

\section{Infra-Red Techniques}

Recently, It has been reported that spectroscopies like mid-infrared (mid-IR), near-infrared (NIR) and Raman in combination with chemometric techniques are highly efficient to discriminate species and also helps in identification of geographical origins of herbal medicines $[46,47]$. However, NIR spectroscopy is widely due to high reliability, low cost and easy analysis of biological evidences such as soil, food and beverages [48-50]. Thus, NIR spectroscopy can be utilized in the identification of wildlife. Molecular methods are being used to identify the origin of species are nuclear DNA, mtDNA and DNA fingerprinting which helps to law enforce of wildlife conservation. Genetic methods have also been used to determine the geographic origin [51-54]. Assignment tests and microsatellites have also been used to determine the origin.

\section{Inductively coupled plasma atomic emission spectroscopy}

This a technique used for the determination different metal ions concentration in the samples. The metal ions concentration profiles of animal samples generally correlates with that of their habitat and it becomes the basis of their place of origin determination. The bones utilized in forensic identification of species are burned, fragmented remains from fires and natural disasters [55-58]. If anatomical characteristics of bones have been damaged, histological analysis can be used for differentiation [59]. In Identification of mammal species, humana \& nonhuman differentiation characteristics of osteon banding and haversian canals is very important. It has also been reported that the presence or absence of plexiform bone, the arrangement of osteons, haversian canals and size is effective in differentiation of non human bones [57]. However, in the cases when bones are damaged, anatomical features not available, becomes fragmented or burned ICP can be a good option to measure the concentration of eight elements (aluminum, boron, calcium, iron, lead, magnesium, potassium, and sodium) within bone fragments.

\section{Radioisotopes tracer techniques}

This technique is used to detect the trace elements in the evidencial remains in wildlife forensic. Radioisotopes are more abundant at different locations and the presence of those radioisotopes provides the information about their most probable origin based on the isotopes abundance maps. There are two main types of elements that are incorporated into the body; essential and trace [60]. The non-essential elements include aluminum, arsenic, beryllium, cadmium, chromium, molybdenum, nickel, lead, and tin [61]. The ingestion and inhalation of trace metals from the diet and environment can lead to increased levels within the body. Thus, radioisotopes tracer techniques are being utilized in detection of origin of species. Mt-DNA marker (16S rRNA, 12S rRNA, cytochrome $\mathrm{b}$ and Cytochrome Oxidase) have also been utilized in identification of geographical origin. When morphological characteristics of species lost in such cases identification based on DNA analysis becomes critical in wildlife forensics [62]. In wildlife forensic mt-DNA marker like 16S rRNA, 12S rRNA, Cytochrome b and Cytochrome Oxidase are used for identification including phylogenetic analysis of the species. These mt-DNA based marker shows interspecific variation. The genetic marker which is available for different species as well as subspecies belongs to different geographical ranges is helpful in wildlife forensics but much of work is needed to create the marker of DNA sequence repository of wildlife flora and fauna at the present and near future [21].

\section{Limitations of protein marker based identification}

The apoptosis process during the hair biogenesis is the major reason behind the poor DNA extraction from hair. In the biogenesis process of hair most of the DNA degraded and only trace of DNA extracted Range of discrimination also has not been established till date.

\section{Discussion}

Non availability of species specific antibodies in serological analysis, undetectable footprint and erosions by the other animals in footprint analysis, requirement of samples in well preserve form in microscopic analysis, lac of taxonomic keys and wild animals monographs are the major limitations in the wildlife forensic. Wildlife protection in the current situation is highly important to restrict or prevent the illegal trade of wildlife flora and fauna. So, prevention of poaching or encroachment in forest reserves and wildlife related crimes is very important. Wildlife forensic helps the law enforcement agency in the conviction of wildlife criminals or smugglers. In India, wildlife forensic is still underdeveloped and wildlife officials are inadequately trained in using forensic science techniques in handling wildlife related crimes. So, having a basic idea about wildlife forensic would greatly increase their potential in handling wildlife related crimes. A single characteristic of a species e.g. hair morphology may be common for other related species. In the case of any ambiguity in species identification it is recommended to integrate the results of more than one technique. Although molecular techniques alone are very accurate and more specific, can identify a species alone, species specific characteristic markers are not available for all species.

\section{Acknowledgement}

SFSL and Police Departments 


\section{References}

1. Cooper JE, Cooper ME (2008) Introduction to veterinary and comparative forensic medicine. Blackwell, Oxford.

2. Lawton MPC, Cooper JE (2009) Wildlife crime scene visits. Appl Herpetol 6: 29-45.

3. Sahajpal V, Goyal SP, Raza R, Jayapal R (2009) Identification of mongoose (genus: Herpestes) species from hair through band pattern studies using discriminate functional analysis (DFA) and microscopic examination. Sci Justice 49: 205-9.

4. Mayer WV (1952) The hair of Californian mammals with keys to dorsal guard hairs of Californian mammals Am Midland Nat 48: 480-512.

5. Sreepada RA, Desai UM, Naik S (2002) The plight of Indian sea horses: need for conservation and management. Indian Academy Sci 82: 377-8.

6. Farnsworth NR, Soejarto DD (1991) Global importance of medicinal plants. Cons med plants 25-51.

7. Vincent AC, Foster SJ, Koldewey HJ (2011) Conservation and management of seahorses and other Syngnathidae. J Fish Biol 78 1681-724.

8. Bell B, Machin S (2011) The impact of migration on crime and victimisation. London: UK.

9. Wong KL, Wang J, But PPH, Shaw PC (2004) Application of cytochrome b DNA sequences for the authentication of endangered snake species. Forensic sci Int 139: 49-55.

10. Chapman DD, Abercrombie DL, Douady CJ, Pikitch EK, Stanhopen MJ, et al. (2003) A streamlined, bi-organelle, multiplex PCR approach to species identification: application to global conservation and trade monitoring of the great white shark, Carcharodon carcharias. Cons Gen 4: 415-25.

11. Moore SE, Grebmeier JM, Davies JR (2003) Gray whale distribution relative to forage habitat in the northern Bering Sea: current conditions and retrospective summary. Canadian J Zoology 81: 734-42.

12. Branicki W, Kupiec T, Pawlowski R (2003) Validation of cytochrome b sequence analysis as a method of species identification. J Forensic Sci 48: 83-7.

13. Del-Prado R, Cubas P, Lumbsch HT, Divakar PK, Blanco O, et al. (2010) Genetic distances within and among species in monophyletic lineages of Parmeliaceae (Ascomycota) as a tool for taxon delimitation. Mol Phyls Evol 56: 125-33.

14. Wasser SP (2007) Molecular identification of species of the genus Agaricus. Why should we look at morphology? Int J Med Mushrooms 9: 85-8.

15. Hsieh HM, Huang LH, Tsai LC, Kuo YC, Meng HH, et al. (2003) Species identification of rhinoceros horns using the cytochrome b gene. Forensic Sci Int 136: $1-11$.

16. Lo TW, Pickle CS, Lin S, Ralston EJ, Gurling M, et al. (2013) Precise and heritable genome editing in evolutionarily diverse nematodes using TALENs and CRISPR/Cas9 to engineer insertions and deletions. Genetics 195: 331-48.

17. Thakur M, Singh SK, Shukla M, Sharma LK, Mohan N (2013) Identification of Galliformes through Forensically Informative Nucleotide Sequencing (FINS) and its Implication in Wildlife Forensics. J Forensic Res 4: 195.

18. Kumar R, Singh PJ, Nagpure NS, Kushwaha B, Srivastava SK, et al. (2007) A non-invasive technique for rapid extraction of DNA from fish scales 45: $992-7$.

19. Verma SK, Goswami GK (2014) DNA evidence: Current perspective and future challenges in India. Forensic sci Int 241: 183-9.

20. Espinosa EO, Mann MJ (1993) The History and Significance of the Schreger Pattern in Proboscidean Ivory Characterization; The American Institute for Conservation of Historic \& Artistic Works 32: 241.

21. Singh RR, Goyal SP, Khanna PP, Mukherjee PK, Sukumar R (2006) Using morphometric and analytical techniques to characterize elephant ivory. Forensic Sci Int 162: 144-51.

22. Linacre A, Tobe SS (2011) An overview of the investigative approach to species testing in wildlife forensic science. Investig Genet 2: 2.

23. Dahiya MS, Yadav SK (2013) Scanning electron microscopic characterization and elemental analysis of hair: a tool in identification of felidae animals. J Forensic Res 4: 1 .

24. Hausman LA (1930) Recent studies of hair structure relationships. Science Monthly 30: 258-77.

25. Cole HI (1924) Taxonomic value of hair in Chiroptera. Philippine J Sci 14: 117-21.

26. Williams CS (1938) Aids to the Identification of Mole and Shrew Hairs with General Comments on Hair Structure and Hair Determination. J Wildlife Man 2: $239-50$.

27. Brown FM (1942) The Microscopy of Mammalian Hair for Anthropologists. Proc American Philos Soc 85: 250-74.

28. Corbet LK (1974) Microscopic identification of Hair structure. Australian Mammalian Society 303.

29. Teerink BJ (1991) Hair of West European Mammals: Atlas and Identification Key. Cambridge University Press 1: 156-200.

30. Saferstein R (1982) In Forensic Science Handbook Chapter 7; Prentice Hall: New Jersey 267-96.

31. Macedo-Silva A, Barbosa SF, Alkmin MG, Vaz AJ, Shimokomaki M, et al. (2000) Hamburger meat identification by dot-ELISA. Meat Sci 56: $189-92$.

32. Bird GWG (1961) Paradoxical findings in Ouchterlony tests. Experientia 17: 408.

33. Wilson-Wilde L, Norman J, Robertson J, Sarre S, Georges A (2010) Current issues in species identification for forensic science and the validity of using the cytochrome oxidase I (COI) gene. Forensic Sci Med Pathol 6: 233-41.

34. An J, Lee MY, Min MS, Lee MH, Lee H (2007) A molecular genetic approach for species identification of mammals and sex determination of birds in a forensic case of poaching from South Korea. Forensic Sci Int 167: 59-61.

35. Hakki EE, Uz E, Sag A, Atasoy S, Akkaya MS (2003) DNA fingerprinting of Cannabis sativa L. accessions using RAPD and AFLP markers. Forensic Sci Int 136: 31 .

36. Adbel-Rahman SM, Ahmed MMM (2007) Rapid and sensitive identification of buffalo's, cattle's and sheep's milk using species-specific PCR and PCR-RFLP techniques. Food Control 18: 1246-9.

37. Verkaar EL, Nijman IJ, Boutaga K, Lenstra JA (2002) Differentiation of cattle species in beef by PCR-RFLP of mitochondrial and satellite DNA. Meat Sci 60: $365-9$.

38. Guha S, Kashyap VK (2006) Molecular identification of lizard by RAPD \& FINS of mitochondrial 16s rRNA gene. Legal Med (Tokyo) 8: 5-10.

39. Welsh J, McClelland M (1990) Fingerprinting genomes using PCR with arbitrary primers. Nucleic Acids Res 18: 7213-8.

40. Comstock KE, Ostrander EA, Wasser SK (2003) Amplifying Nuclear and Mitochondrial DNA from African Elephant Ivory: a Tool for Monitoring the Ivory Trade. Conservation Biology 17: 1840-3. 
41. Caniglia R, Fabbri E, Greco C, Galaverni M, Randi E (2010) Forensic DNA against wildlife poaching: identification of a serial wolf killing in Italy. Forensic Sci Int Genet 4: 334-8.

42. van Oorschot RA, Ballantyne KN, Mitchell RJ (2010) Forensic trace DNA: a review. Investig Genet 1: 14.

43. Orlando L, Ginolhac A, Zhang G, Froese D, Albrechtsen A, et al. (2013) Recalibrating Equus evolution using the genome sequence of an early Middle Pleistocene horse. Nature 499: 74-8.

44. Allentoft ME, Sikora M, Sjögren KG, Rasmussen S, Rasmussen M, et al. (2015) Population genomics of Bronze Age Eurasia. Nature 522: 167-72.

45. Wadsworth C, Buckley M (2014) Proteome degradation in fossils: investigating the longevity of protein survival in ancient bone. Rapid Commun Mass Spectrom 28: 605-15

46. Rohman A, Nugroho A, Lukitaningsih E, Sudjadi (2014) Application of Vibrational Spectroscopy in Combination with Chemometrics Techniques for Authentication of Herbal Medicine. Appl Spectrosc Rev 49: 603-13.

47. Laasonen M, Harmia-Pulkkinen T, Simard CL, Michiels E, Räsänen M, et al. (2002) Fast identification of Echinacea purpurea dried roots using near-infrared spectroscopy. Anal Chem 74: 2493-9.

48. Chang CW, Laird DA, Mausbach MJ, Hurburgh CR (2001) Near-Infrared Reflectance Spectroscopy-Principal Components Regression Analyses of Soil Properties. Soil Sci Soc Am J 65: 480-90.

49. Cen H, He Y (2007) Theory and application of near infrared reflectance spectroscopy in determination of food quality. Trends Food Sci Tech 18: 72-83.

50. Huang H, Yu H, Xu H, Ying Y (2008) Near infrared spectroscopy for on/in-line monitoring of quality in foods and beverages: A review. J Food Eng 87: 303-13.

51. Palumbi SR, Cipriano F (1998) Species identification using genetic tools: the value of nuclear and mitochondrial gene sequences in whale conservation. J Hered 89: 459-64.

52. Roman J, Bowen BW (2000) The mock turtle syndrome: genetic identification of turtle meat purchased in the south-eastern United States of America. Anim Conservation 3: 61-5.

53. Waits L, Taberlet P, Swenson JE, Sandegren F, Franzén R (2000) Nuclear DNA microsatellite analysis of genetic diversity and gene flow in the Scandinavian brown bear (Ursus arctos). Mol Ecol 9: 421-31.

54. Seeb JE, Kruse GH, Seeb LW, Weck RG (1990) Genetic structure of red king crab populations in Alaska facilitates enforcement of fishing regulations. Proc Int symposium on King and Tanner crabs. Alaska Sea Grant, Fairbank 491-502.

55. Martiniaková M, Grosskopf B, Omelka R, Vondráková M, Bauerová M (2006) Differences among species in compact bone tissue microstructure of mammalian skeleton: use of a discriminant function analysis for species identification. J Forensic Sci 51: 1235-9.

56. Hollmann T, Byard RW, Tsokos M (2008) The processing of skeletonized human remains found in Berlin, Germany. J Forensic Leg Med 15: $420-5$.

57. Hillier ML, Bell LS (2007) Differentiating human bone from animal bone: a review of histological methods. J Forensic Sci 52: $249-63$.

58. Ubelaker DH (2009) The forensic evaluation of burned skeletal remains: a synthesis. Forensic Sci Int 183: 1-5.

59. Cuijpers AGFM (2006) Histological identification of bone fragments in archaeology: telling humans apart from horses and cattle. Int J Osteoarchaeol 16: 46580.

60. Kuo HW, Kuo SM, Chou CH, Lee TC (2000) Determination of 14 elements in Taiwanese bones. Sci Total Environ 255: 45-54.

61. Kakuschke A, Griesel S, Fonfara S, Rosenberger T, Prange A (2008) Concentrations of Selected Essential and Non-Essential Elements in Blood of Harbor Seal (Phoca Vitulina) Pups of the German North Sea. Biol Trace Elem Res 127: 28-36.

62. Ogden R, Dawnay N, McEwing R (2009) Wildlife DNA forensics_bridging the gap between conservation genetics and law enforcement. Endang Species Res 9: 179-95. 